\title{
Strategic Trade Policy under Integrated Markets
}

\author{
David R. Collie \\ Cardiff University \\ Morten Hviid \\ University of Warwick \\ Toby Kendall \\ University of Birmingham
}

\begin{abstract}
A model of strategic trade policy under integrated markets is presented and optimal trade policies are derived under assumptions of both complete and incomplete information. With the assumption of complete information it is shown that the optimal policy is an import tariff (export subsidy) when a country is a net importer (exporter). In the Nash equilibrium in trade policies the low cost country gives an export subsidy which is fully countervailed by the import tariff of the other country. The introduction of incomplete information about costs adds an incentive for both governments to use their trade policy as a signal of their firm's costs. This signalling effect increases the export subsidy and decreases the import tariff. In the simultaneous signalling game, with symmetry, the expected welfare in the separating equilibrium is higher than under free trade for both countries. (JEL Classifications: F12, F13, L13) < Key Words: integrated markets, incomplete information, signalling, subsidies, tariffs.>

\footnotetext{
* Correspondence Address: Morten Hviid, Department of Economics, University of Warwick, Coventry, CV4 7AL, United Kingdom; (E-mail) M.Hviid@warwick.ac.uk. (C)1999 - Institute for International Economics, Sejong Institution. All rights reserved.
} 


\section{Introduction}

The trade policy literature has identified two main cases where intervention in international trade may be welfare improving for a country. In conventional trade theory, a large country able to influence its terms of trade can gain by using an optimum tariff and, in the new trade theory, a country can use strategic trade policies to shift profits to the domestic firm and/or to extract rent from foreign firms. In both these cases, trade policy is generally a beggar-my-neighbour policy where intervention by one country increases its welfare at the expense of the other country. When both countries intervene, setting trade policy in a non-cooperative manner, the outcome will typically be a prisoners' dilemma where both countries are worse off and aggregate world welfare is undoubtedly lower than under free trade. ${ }^{1}$ In contrast, this paper presents a model of strategic trade policy under integrated markets, with incomplete information about costs, where non-cooperative trade policy setting yields higher welfare than under free trade for both countries. ${ }^{2}$

Although the literature on strategic trade policy is now very extensive, see Brander [1995] for a recent survey, it has concentrated almost exclusively on the case of segmented markets with only a few papers dealing with the case of integrated markets. ${ }^{3}$ The assumption of segmented markets means that there is no possibility of arbitrage between markets so firms regard each country as a separate market. Together with the usual assumption of constant marginal cost this implies that one market can be analyzed

1. As Johnson [1953-54] has shown, in the case of the terms of trade argument, one country may gain compared to free trade but the other country will always lose. Similar results have also been obtained in strategic trade policy models.

2. Other papers that look at Pareto-improving trade policy, such as Anis and Ross [1992], consider a policy change by one country that improves the welfare of both countries but they do not show that non-cooperative trade policy setting yields higher welfare for both countries than under free trade. Bagwell and Staiger [1989] present a model where export subsidies are used to signal product quality and where intervention by both governments can be welfare improving.

3. Notable exceptions that deal with trade policy under integrated markets are Fisher [1985], Markusen and Venables [1988], Venables [1994], and Fisher and Wilson [1995]. 
independently of any other markets which greatly simplifies the analysis of trade policy. However, the lack of any interaction between markets is a very unappealing feature of these models. The alternative assumption of integrated markets means that there is perfect arbitrage between markets, and hence firms sell in an integrated world market. In the absence of transport costs, perfect arbitrage implies that any price differences between markets must be entirely due to trade policies. Thus, with integrated markets it is not possible to analyze one market independently of the others, making the modeling of strategic trade policy under integrated markets more difficult than when markets are segmented. With world markets becoming more integrated, the assumption of segmented markets seems less tenable when firms regard the global economy as their market place. Consequently, the first aim of this paper is to analyze strategic trade policy under integrated markets with complete information. ${ }^{4}$

A recent innovation in the literature on strategic trade policy has been the introduction of incomplete information. ${ }^{5}$ In a Cournot duopoly model based upon Brander and Spencer [1985], Collie and Hviid [1993] show that an export subsidy can be used to signal about the competitiveness of the domestic firm when the foreign firm has incomplete information about the domestic firm's costs. Similarly, Collie and Hviid [1999] show that a tariff can be used to signal the uncompetitiveness of the domestic firm when incomplete information about costs is added to the Brander and Spencer [1984] model. Brainard and Martimort [1996] extend the Brander and Spencer [1985] model of profit-shifting export subsidies by assuming that the domestic government has incomplete information about the costs of the domestic firm. Assuming that the collection of government revenue is costly, they derive the optimal export subsidy and lump-sum payment scheme that ensures the truthful revelation of costs by the domestic firm. The model analyzed by Qiu [1994] combines both signalling and truthful revela-

4. Strategic trade policy under integrated markets has been analyzed by Markusen and Venables [1988], but they do not consider the optimal policy only small deviations from free trade.

5. Apart from this paper, the rest of the literature on strategic trade policy under incomplete information assumes that markets are segmented. 
tion under Cournot and Bertrand oligopoly. As Brander [1995] notes in his survey of strategic trade policy " $(t)$ he existence of informational asymmetries seems both indisputable and important". Therefore, the second aim of this paper is to introduce incomplete information about the costs of both firms into the model of strategic trade policy under integrated markets, and to analyze how both governments can use trade policy to signal about the costs of their domestic firm.

Section II of this paper presents the model of strategic trade policy under integrated markets with complete information, where two firms each located in a separate country compete as Cournot duopolists in an integrated world market. In section III, the optimal trade policy of a country is shown to be an import tariff if the country is a net importer and an export subsidy if the country is a net exporter. When both countries set trade policy noncooperatively, the outcome is the Nash equilibrium in trade policies where the country that has the firm with the lowest costs will give an export subsidy which is fully countervailed by the import tariff set by the other country. The country that has the firm with the lowest cost will be worse off while the other country will be better off than under free trade. Section IV extends the model presented in section two by adding incomplete information about the costs of the two firms. The separating equilibria of this signalling game are derived in section V. Taking the expected trade policy of the other country as given, it is shown that a country can use its trade policy to signal about the domestic firm's costs. The export subsidy (import tariff) in the separating equilibrium is larger (smaller) than the optimum under complete information. Section VI derives the separating equilibrium of the simultaneous signalling game, and shows that the country with the low (high) cost firm will have the highest (lowest) expected trade policy. Expected world welfare in the separating equilibrium is shown to be higher than under free trade and, in the symmetric case, both countries are better off in the separating equilibrium. This gain in worldwide efficiency arises from increased specialization according to comparative advantage.

\section{The Basic Model with Complete Information}

The world economy consists of two countries: country one and country 
two; variables relating to country one will be labeled by a subscript one and those relating to country two by a subscript two. The markets of the two countries are integrated; hence, in the absence of transport costs, perfect arbitrage ensures that any price difference between the two markets is due entirely to trade taxes and subsidies. A single firm is located in each country and these two firms compete as Cournot duopolists in the integrated world market. Demand in the two markets is assumed to be identical and given by the linear demand functions $y_{i}=\alpha-\beta p_{i}$ for $i=1,2$, where $y_{i}$ is consumption and $p_{i}$ is the consumer price in the ith market. The firm in the $i$ th country has constant marginal cost $c_{i}$ and produces output $x_{i}$; it is assumed that $c_{i}<\alpha / \beta$ since otherwise a firm will never produce any output. Net imports of the $i$ th country are given by domestic consumption minus domestic production: $m_{i}=y_{i}-x_{i}$. With only two countries, market clearing will ensure that total consumption of the good is equal to total production of the good in the integrated world market so $y_{1}+y_{2}=x_{i}+x_{2}$ which implies that $m_{1}+m_{2}=0$.

The governments of the two countries each set trade policy to maximize their national welfare. In the ith country, the government uses a trade policy $t_{i}$ (a tariff on imports combined with a subsidy to exports) which increases the price in its domestic market relative to the price in the foreign market by the amount of the trade policy $t_{i}$. There are three main reasons for using this combined trade policy instrument rather than conventional import tariffs and export subsidies: Firstly, it greatly simplifies the analysis of trade policy under integrated markets as it implies an arbitrage condition that holds with equality instead of the two inequalities implied by the use of conventional trade policy. Secondly, export subsidies have to be combined with import tariffs to prevent arbitrageurs continually exporting then re-importing and re-exporting the goods. Thirdly, conventional import tariffs artificially segment markets and are anti-competitive whereas this combined trade policy instrument keeps markets integrated. ${ }^{6}$ Implicitly, and possibly

6. The anti-competitive effect of conventional tariffs when markets are integrated has been shown by Venables [1994] and Fisher and Wilson [1995] under Bertrand oligopoly, and Collie [1998] has shown how this combined trade policy instrument will avoid these anti-competitive effects. 
unwittingly, Markusen and Venables [1988] assume the use of the same combined trade policy instrument since they also require that producer prices are equal in the two countries with integrated markets.

Formally, trade policy setting is modeled as a two stage game where the two governments simultaneously set trade policies in the first stage, and then in the second stage the two firms compete as Cournot duopolists given the trade policies set by the two governments. As usual, the game is solved for the subgame perfect equilibrium by backwards induction.

Demand in the integrated world market is the sum of demand in the two countries. Since the two markets are integrated, perfect arbitrage will ensure that consumer prices in the two markets will differ only by the amount of any trade policies which implies that, for each firm, producer prices are equal in the two countries so that $p_{1}-t_{1}=p_{2}-t_{2}$. Summing the demand functions in the two countries, then using the arbitrage and market clearing conditions, yields the inverse demand functions facing the two firms in the integrated world market as functions of their outputs:

$$
p_{i}=\frac{\alpha}{\beta}-\frac{x_{i}+x_{j}}{2 \beta}+\frac{t_{i}-t_{j}}{2} \quad i, j=1,2 \quad i \neq j
$$

Hence, the slope of the inverse demand function facing the $i$ th firm is $\partial p_{i} / \partial x_{i}=-1 / 2 \beta$. The two firms compete as Cournot duopolists in the integrated world market, and the profits of the firm in the $i$ th country are $\pi_{i}=\left(p_{i}\right.$ $-c_{i}$ ) $x_{i}$. Assuming an interior solution where both firms produce positive output, the first order conditions for the Cournot-Nash equilibrium are:

$$
\frac{\partial \pi_{i}}{\partial x_{i}}=p_{i}-c_{i}+x_{i} \frac{\partial p_{i}}{\partial x_{i}}=0 \quad i, j=1,2 \quad i \neq j
$$

Substituting the inverse demand functions (1) into these first order conditions and then solving for the Cournot-Nash equilibrium outputs yields ${ }^{7}$

$$
x_{i}=\frac{2}{3}\left(\alpha-2 \beta c_{i}+\beta c_{j}\right)+\beta\left(t_{i}-t_{j}\right) \quad i, j=1,2 \quad i \neq j
$$

7. With linear demand, since profit functions are concave, the second-order conditions for profit-maximization are satisfied and there exists a unique Cournot equilibrium. 
The effect of an import tariff or export subsidy, $t_{i}$, is to increase the output of the domestic firm, $\partial x_{i} / \partial t_{i}=\beta$, and to reduce the output of the foreign firm by an equal amount, $\partial x_{j} / \partial t_{i}=-\beta$; therefore, total production in the integrated world market is unchanged. Using the Cournot-Nash equilibrium outputs (3) in the inverse demand functions (1) yields the prices in the two markets:

$$
p_{i}=\frac{1}{3 \beta}\left(\alpha+\beta c_{1}+\beta c_{2}\right)+\frac{1}{2}\left(t_{i}-t_{j}\right) \quad i, j=1,2 \quad i \neq j
$$

The effects of trade policy, $t_{i}$, on prices in the two markets are and $\partial p_{j} / \partial t_{i}$ $=1 / 2$ and $\partial p_{j} / \partial t_{i}=-1 / 2$; hence, half of an import tariff is passed through to domestic consumers while half is absorbed by the foreign firm, and half of an export subsidy is passed through to foreign consumers while half is absorbed by the domestic firm. Substituting these prices (4) into the demand functions of the two countries gives consumption in the two markets:

$$
y_{i}=\frac{1}{3}\left(2 \alpha-\beta c_{1}-\beta c_{2}\right)-\frac{\beta}{2}\left(t_{i}-t_{j}\right) \quad i, j=1,2 \quad i \neq j
$$

Trade policy, $t_{i}$, reduces consumption in the domestic market, $\partial y_{i} / \partial t_{i}=$ $-\beta / 2$, and increases consumption in the foreign market by the same amount, $\partial y_{i} / \partial t_{i}=\beta / 2$; therefore, total consumption in the integrated world market is unchanged. Net imports are the difference between domestic consumption and domestic production in a country so $m_{i}=y_{i}-x_{i}$ and market clearing implies that $m_{i}=-m_{j}$; hence, using (3) and (5), net imports of ith country are:

$$
m_{i}=\beta\left(c_{i}-c_{j}\right)-\frac{3 \beta}{2}\left(t_{i}-t_{j}\right)=-m_{j} \quad i, j=1,2 \quad i \neq j
$$

Since trade policy, $t_{i}$, increases domestic production and reduces domestic consumption, it will reduce the $i$ th country's net imports, $\partial m_{i} / \partial t_{i}=$ $-3 \beta / 2$, and increase the other country's net imports by the same amount, $\partial m_{j} / \partial t_{i}=3 \beta / 2$.

Equations (3) to (6) describe the equilibrium of the integrated world market as a function of the trade policies set by the two governments. Ignoring distributional questions and assuming that preferences are quasi-linear, the 
welfare of a country is given by the sum of consumer surplus, the profits of the domestic firm, and government revenue from trade policy. ${ }^{8}$ Thus, the welfare of the two countries are given by:

$$
W_{i}=\frac{1}{\beta} \int_{0}^{y_{i}}(\alpha-\beta q) d q-p_{i} y_{i}+\pi_{i}+t_{i} m_{i}=\frac{1}{2 \beta} y_{i}^{2}+\left(p_{i}-c_{i}\right) x_{i}+t_{i} m_{i} \quad i=1,2
$$

Before looking at trade policy, the question of whether there are gains from trade under oligopoly with integrated markets will be briefly considered. Setting $t_{1}=t_{2}=0$ in (3) to (6) gives output, prices, consumption and net imports under free trade, and substituting these into (7) yields the welfare of the ith country under free trade:

$$
W_{i}^{F}=\frac{2}{9 \beta}\left(2 \alpha-\beta c_{i}-\beta c_{j}\right)\left(\alpha-2 \beta c_{i}+\beta c_{j}\right)+\frac{\beta}{2}\left(c_{i}-c_{j}\right)^{2} \quad i, j=1,2 \quad i \neq j
$$

In autarky, since the domestic firm faces no competition from the foreign firm, it can set the monopoly price in the domestic market and earn monopoly profits. It is straightforward to show that the welfare of the $i$ th country under autarky is $W_{i}^{A}=3\left(\alpha-\beta c_{i}\right)^{2} / 8 \beta$, and obviously there are gains from trade if $\Delta W_{i}=W_{i}^{F}-W_{i}^{A}>0$. It can be shown that $\Delta W_{i}$ : has a minimum at $c_{i}=\left(13 \alpha+28 \beta c_{j}\right) / 41 \beta$ where its value is $\Delta W_{i}=\left(\alpha-\beta c_{j}\right)^{2} / 82 \beta>0$; hence, there are always gains from trade whatever the relative costs of the two firms. ${ }^{9}$ In other models of international trade with imperfect competition under integrated markets, such as Markusen [1981], it is generally shown that a sufficient condition for gains from trade is that the output of the domestic industry expands under free trade. Here, it has been shown that there are gains from trade even if the output of the domestic firm contracts under free trade. An important point to note is that there will be gains from

8. For an import tariff, government revenue is positive since trade policy is positive and net imports are positive while, for an export subsidy, government revenue is negative since trade policy is positive and net imports are negative.

9. The assumption that demand in both markets is identical is important, since it is possible that a country could lose from trade if its market was much larger than the market in the other country, see Markusen [1981]. Surprisingly, this suggests that cost differences should be a less important issue in trade liberalization than differences in the size of the markets. 
trade in the symmetric case, when both firms have the same costs, even though net imports will be equal to zero. These gains arise from the possibility of trade that introduces competition between the two firms, leading to lower prices, and a consequent reduction in the deadweight loss from monopoly.

\section{Trade Policy with Complete Information}

In this oligopolistic industry, a government can use trade policy to shift profits to its domestic firm and to improve the terms of trade by extracting rent from the foreign firm. This section firstly analyzes the optimal trade policy of a country while taking the trade policy of the other country as given, and then analyzes the Nash equilibrium in trade policies when both countries simultaneously set trade polices. The optimal trade policy for the $i$ th country is given by maximizing its welfare (7) with respect to $t_{i}$, while taking $t_{j}$ as given, which yields the first order condition:

$$
\frac{\partial W_{i}}{\partial t_{i}}=m_{i}\left(1-\frac{\partial p_{i}}{\partial t_{i}}\right)+\left(p_{i}-c_{i}\right) \frac{\partial x_{i}}{\partial t_{i}}+t_{i} \frac{\partial m_{i}}{\partial t_{i}}=0 \quad i=1,2
$$

Solving for the optimal trade policy yields:

$$
t_{i}^{*}=\left(m_{i}\left(1-\frac{\partial p_{i}}{\partial t_{i}}\right)+\left(p_{i}-c_{i}\right) \frac{\partial x_{i}}{\partial t_{i}}\right) /\left(-\frac{\partial m_{i}}{\partial t_{i}}\right) \quad i=1,2
$$

Since the denominator is clearly positive, the overall sign of the optimal trade policy depends upon the terms in the numerator. The first term in the numerator is the terms of trade effect which is positive (negative) if net imports are positive (negative) and the second term is the profit-shifting effect which is positive. Hence, if a country is a net importer then the optimal trade policy is an import tariff, but if it is a net exporter then the optimal policy seems to be ambiguous. However, noting that $p_{i}-c_{i}=x_{i} / 2 \beta$ from (1) and (2), that $\partial x_{i} / \partial t_{i}=\beta$ from (3), and that $\partial p_{i} / \partial t_{i}=1 / 2$ from (4), the optimal trade policy can be shown to be $t_{i}^{*}=y_{i} / 3 \beta$ which is positive if domestic consumption is positive; this leads to the following proposition: 
Proposition 1: The optimal trade policy for a country is an import tariff if it is a net importer and an export subsidy if it is a net exporter.

When the country is a net importer, both the terms of trade effect and the profit-shifting effect are positive, hence the optimal policy is a positive import tariff which is similar to the result in Brander and Spencer [1984] for segmented markets. When the country is a net exporter, the positive profitshifting effect outweighs the negative terms of trade effect, hence the optimal policy is an export subsidy which is similar to the result in Brander and Spencer [1985] for segmented markets. The optimal policies under integrated markets are generally smaller than those under segmented markets as the greater degree of competition results in smaller price-cost margins and thus reduces the effect of strategic trade policies. The analysis can be extended to the case of many firms in each country without much difficulty. If the country is a net importer then the optimal policy is always an import tariff, but if the country is a net exporter then the optimal policy may be an export tax if the number of domestic firms is large relative to the number of foreign firms as in Dixit [1984] for segmented markets. The analysis can also be extended to the case when the country uses a production subsidy as well as trade policy. In this case, the optimal policy is a production subsidy to ensure that price is equal to the marginal cost of the domestic firm and an import tariff or export tax to improve the terms of trade.

When both governments set trade policy non-cooperatively the result will be a trade policy war which is best analyzed as the Nash equilibrium of this single-shot game. In the Nash equilibrium in trade policies, each government simultaneously and independently sets trade policy to maximize its national welfare. The first step in analyzing the Nash equilibrium is to derive the best-reply functions that give the optimal trade policy of the $i$ th country as a function of the trade policy of the $j$ th country. Using equations (3) to (6), equation (10) can be solved to give an explicit expression for the bestreply functions:

$$
t_{i}^{*}\left(t_{j}\right)=\frac{2}{21 \beta}\left(2 \alpha-\beta c_{1}-\beta c_{2}\right)+\frac{1}{7} t_{j}>0 \quad i, j=1,2 \quad i \neq j
$$


These best-reply functions show that the optimal response of the ith country to an increase in the trade policy of the $j$ th country is to increase its trade policy, $\partial t_{i}^{*} / \partial t_{j}=1 / 7$. As the best-reply functions of the two countries are upward sloping, the trade policies of the two countries are strategic complements in the terminology of Bulow et al [1985]. Thus, in response to a foreign export subsidy, a country should impose a countervailing duty equal to one-seventh of the foreign export subsidy. This countervailing duty fraction is smaller than the fraction of one-third obtained by Dixit (1984) for segmented markets. Surprisingly, in response to a foreign import tariff, a country should increase its export subsidy by one-seventh of the amount of the tariff. This is in sharp contrast to the results under segmented markets where the optimal response to a foreign tariff is to reduce the export subsidy by half the amount of the tariff..$^{10}$

The two best-reply functions are shown in figure 1 together with the isowelfare loci of country one for the symmetric case when both firms have the same marginal cost $\left(c_{1}=c_{2}\right)$. Along the diagonal, where $t_{1}=t_{2}$, it can be seen from equations (3) to (6) that prices, output and consumption in both countries are the same as under free trade while net imports are equal to zero, $m_{1}=m_{2}=0$. Hence, the welfare of country one is constant along the diagonal, and this helps to explain the unorthodox shape of the iso-welfare loci. When country one is a net importer its welfare is increasing in country two's trade policy (export subsidy), and when country one is a net exporter its welfare is decreasing in country two's trade policy (import tariff). The asymmetric case, when the firm in country one has a cost disadvantage, $c_{1}>c_{2}$, is shown in figure $2 .^{11}$

The Nash equilibrium in trade policies is given by the intersection of the

10. Collie [1994] derives the trade policy best-reply functions and the Nash equilibrium in trade policies under segmented markets when the domestic country uses an import tariff and the foreign country uses an export subsidy.

11. In the asymmetric case, when the two firms do not have the same costs, the line where net imports are equal to zero is below (above) the diagonal if country one's firm has lower (higher) costs than country two's firm. As above, welfare in each country is constant along the line where net imports are zero and the welfare of country one is increasing (decreasing) in country two's trade policy if country one is a net exporter (importer). 


\section{Figure 1}

\section{Trade Policy Best-Reply Functions in the Symmetric Case}

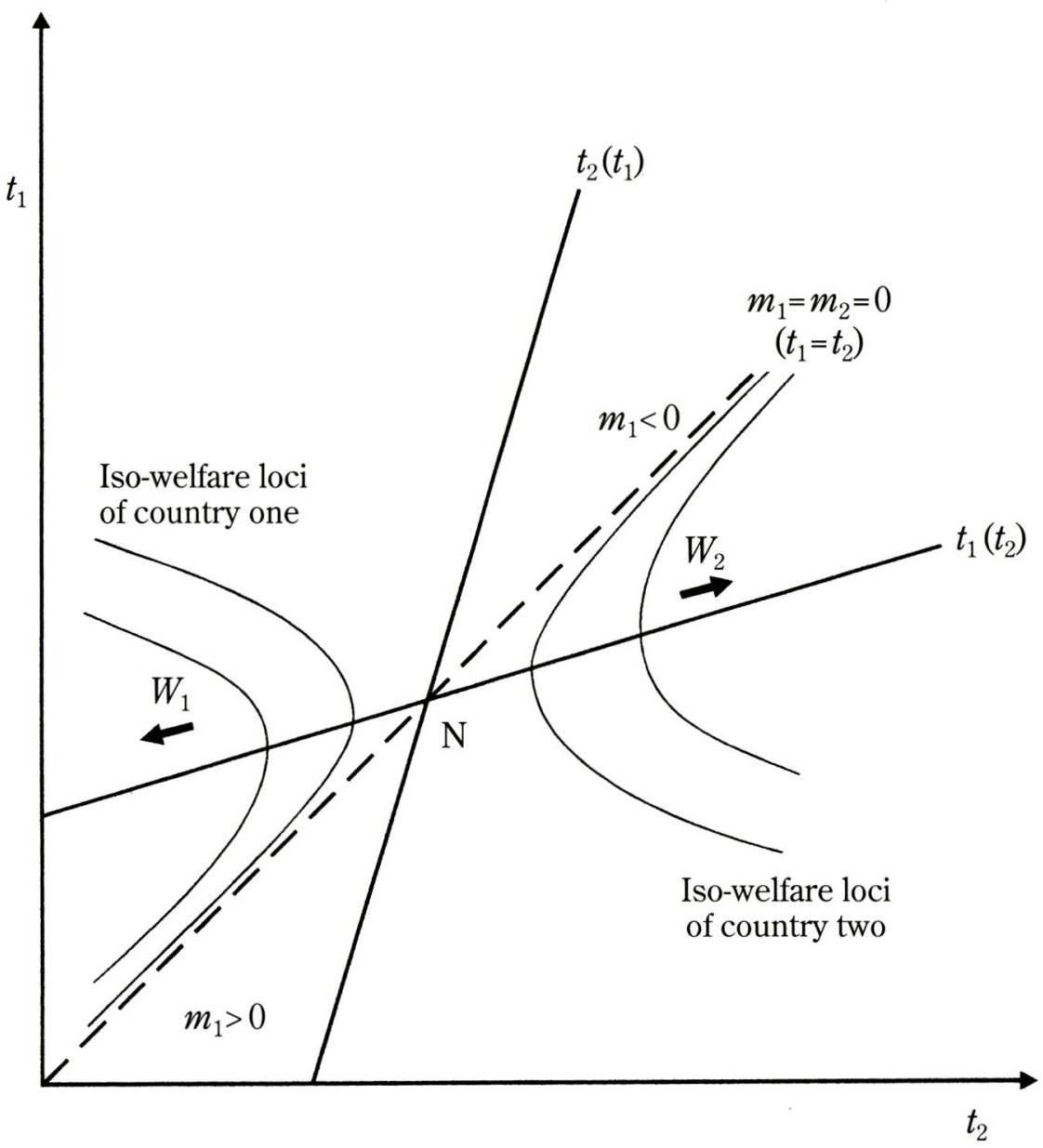

two best-reply functions as shown in figures 1 and 2. Using (11) to solve for the intersection of the two best-reply functions yields the Nash equilibrium trade policies:

$$
t_{1}^{N}=t_{2}^{N}=\left(2 \alpha-\beta c_{1}-\beta c_{2}\right) / 9 \beta>0
$$

In the Nash equilibrium, both countries set their trade policy at exactly the same level. ${ }^{12}$ Noting that the country with the low (high) cost firm will 
Figure 2

\section{Trade Policy Best-Reply Functions for the Asymmetric Case}

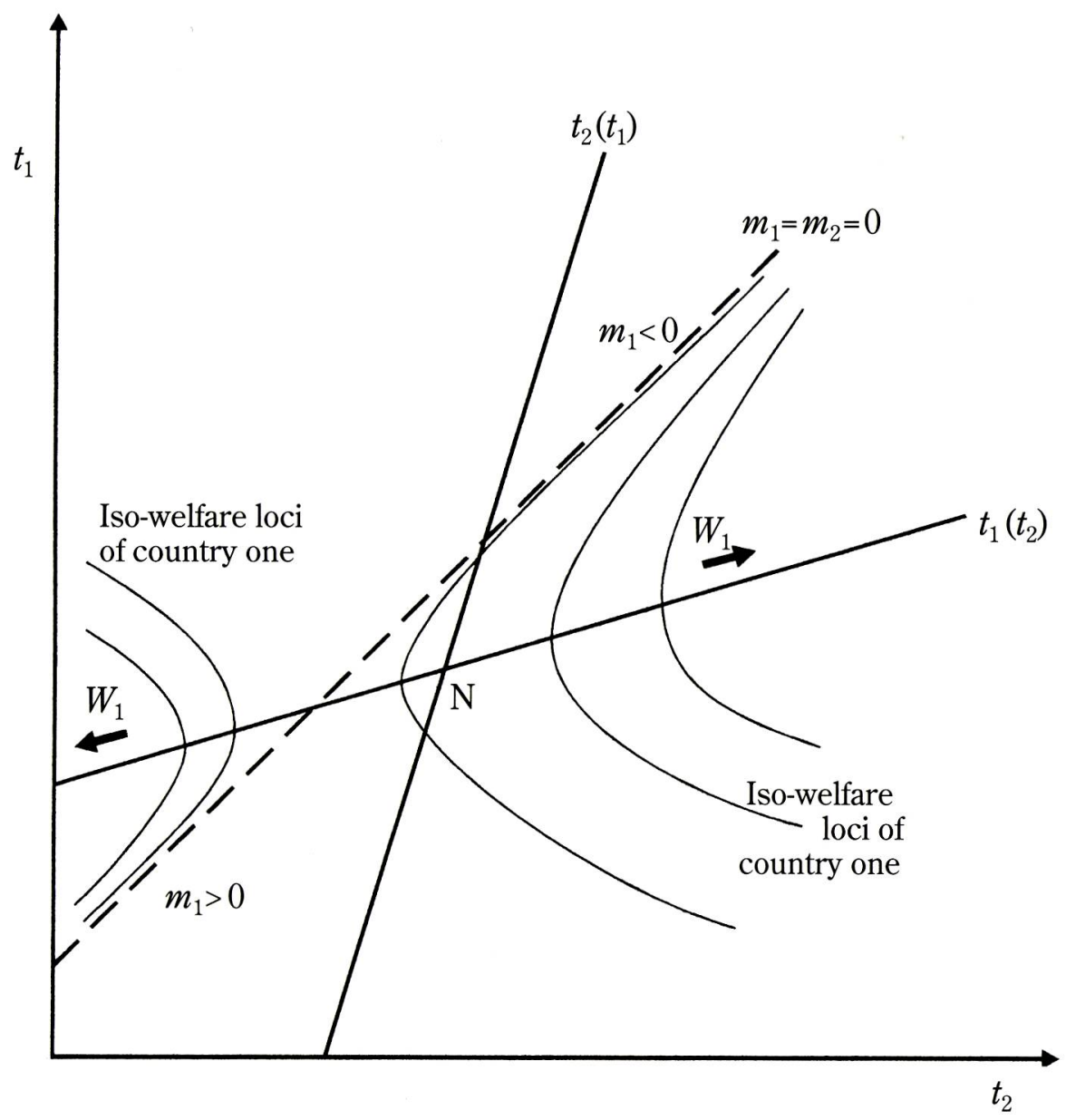

be a net exporter (importer) in the Nash equilibrium in trade policies since $m_{1}=\beta\left(c_{1}-c_{2}\right)=-m_{2}$, leads to the following proposition:

12. Although not directly comparable, this result can be contrasted with that in de Meza [1986] which shows that the country with the low (high) cost firm will give the largest (smallest) Nash equilibrium export subsidy in the Brander and Spencer [1985] model under segmented markets. Here, although costs do affect the Nash equilibrium trade policies, cost differences do not lead to differences in the Nash equilibrium trade policies of the two countries. 
Proposition 2: In the Nash equilibrium in trade policies, the country with the low cost firm gives an export subsidy which is fully countervailed by the import tariff set by the other country.

Comparing the Nash equilibrium in trade policies with free trade, it is obvious that the country with the low cost firm is made worse off while the other country is made better off since the net effect of the import tariff and the export subsidy is to transfer revenue from the exporting country to the importing country. World welfare in the Nash equilibrium is the same as under free trade. This analysis suggests that a country like Japan, which is a net exporter of oligopolistic products such as cars, will lose in a trade war with a net importer like the United States.

\section{Incomplete Information about Costs}

In this section, incomplete information about costs is added to the basic model presented in section II. Each firm is assumed to have incomplete information about its competitor's marginal cost while each government knows the marginal cost of its domestic firm but not that of the foreign firm. ${ }^{13}$ In this situation, the trade policy set by a government may provide a signal to the foreign firm about the costs of the domestic firm, and the governments will take this signalling effect into account when setting trade policy. This game of incomplete information has two stages: At the first stage, the two governments each observe the marginal cost of their domestic firm and set their trade policy to maximize their national welfare. Then, at the second stage, the two firms having observed the trade policies set by the two governments, which they use to infer the marginal cost of their foreign competitor, independently and simultaneously choose their outputs to maximize their profits.

The marginal cost of the firm in the $i$ th country, $c_{i}$, is assumed to be drawn from a continuous probability distribution with support on $\left[c_{i}^{L}, c_{i}^{H}\right]$

13. The governments may directly observe the marginal cost of the domestic firm or each may design a mechanism to ensure that the firm truthfully reveals its costs as in Brainard and Martimort [1996]. 
and with unconditional mean $\bar{c}_{i}$ and variance $\sigma_{i}^{2}$. The two probability distributions are assumed to be independently distributed, and to be common knowledge to both firms and both governments. The expected profits of the firm in the $i$ th country are $\pi_{i}=E_{i}\left[\left(p_{i}-c_{i}\right) x_{i} \mid t_{i}\right]$ where $E_{i}$ is the expectation operator given the firm's beliefs about the marginal cost of the foreign firm. Assuming an interior solution, the first-order conditions for the BayesianNash equilibrium are:

$$
\begin{aligned}
\frac{\partial \pi_{i}}{\partial x_{i}} & =E\left[\left(p_{i}-c_{i}+x_{i} \frac{\partial p_{i}}{\partial x_{i}}\right) t_{j}\right] \\
& =\frac{1}{2 \beta}\left(2 \alpha-E_{i}\left(x_{j} \mid t_{j}\right)-2 x_{i}+\beta t_{i}-\beta t_{j}-\beta c_{i}\right)=0, \quad i, j=1,2 \quad i \neq j
\end{aligned}
$$

In order to solve for Bayesian-Nash equilibrium quantities, it is first necessary to determine each firm's expectation of its competitor's output, $E_{i}\left(x_{j}\right.$ $\left.\mid t_{j}\right]$. Taking expectations of the two firms' first-order conditions, using the common knowledge assumption, then solving the two simultaneous equations for the expected outputs yields:

$$
E_{i}\left(x_{j} \mid t_{j}\right)=\frac{2}{3}\left(\alpha-2 \beta \hat{c}_{j}+\beta \hat{c}_{i}\right)+\beta\left(t_{j}-t_{i}\right) \quad i, j=1,2 \quad i \neq j
$$

where $\hat{c}_{i}=\hat{c}_{i}\left(t_{i}\right)=E_{j}\left(c_{i} \mid t_{i}\right)$ is the jth firm's expectation of its competitor's marginal cost conditioned on the trade policy set by the government of the $i$ th country. Substituting (14) into (13), then solving for the Bayesian-Nash equilibrium outputs of the two firms yields:

$$
x_{i}=\frac{1}{3}\left(2 \alpha-3 \beta c_{i}-\beta \hat{c}_{i}+2 \beta \hat{c}_{j}\right)+\beta\left(t_{i}-t_{j}\right) \quad i, j=1,2 \quad i \neq j
$$

Using these outputs in the inverse demand functions (1) gives the prices in the two countries:

$$
p_{i}=\frac{1}{6 \beta}\left(2 \alpha+3 \beta c_{i}-\beta \hat{c}_{i}+3 \beta c_{j}-\beta \hat{c}_{j}\right)+\frac{1}{2}\left(t_{i}-t_{j}\right) \quad i, j=1,2 \quad i \neq j
$$

Consumption in each country can be found by using these prices in the demand functions of the individual countries: 


$$
y_{i}=\frac{1}{6}\left(4 \alpha-3 \beta c_{i}+\beta \hat{c}_{i}-3 \beta c_{j}+\beta \hat{c}_{j}\right)+\frac{\beta}{2}\left(t_{i}-t_{j}\right) \quad i, j=1,2 \quad i \neq j
$$

Net imports in each country are given by the difference between domestic consumption and domestic production in each country, hence:

$$
m_{i}=\frac{\beta}{2}\left(c_{i}+\hat{c}_{i}-c_{j}-\hat{c}_{j}\right)-\frac{3 \beta}{2}\left(t_{i}-t_{j}\right)=-m_{j} \quad i, j=1,2 \quad i \neq j
$$

As in section two, the welfare of the $i$ th country is given by the sum of consumer surplus, the profits of the domestic firm, and government revenue. Using equations (15) to (18) to evaluate the expected welfare of the ith country, $W_{i}\left(t_{i}, c_{i}, \hat{c}_{i} ; t_{j}, c_{j}, \hat{c}_{j}\right)$, yields:

$$
\begin{aligned}
W_{i}= & \frac{1}{72} E_{i}\left[32 \alpha^{2} / \beta-72 \alpha c_{i}-8 \alpha \hat{c}_{i}+16 \alpha \hat{c}_{j}+24 \alpha t_{i}-24 \alpha t_{j}+45 \beta c_{i}^{2}+18 \beta c_{i} \hat{c}_{i}\right. \\
& -18 \beta c_{i} c_{j}-18 \beta c_{i} \hat{c}_{j}-18 \beta c_{i} t_{i}+54 \beta c_{i} t_{j}+5 \beta \hat{c}_{i}^{2}-18 \beta \hat{c}_{i} c_{j}-2 \beta \hat{c}_{i} \hat{c}_{j}+6 \beta \hat{c}_{i} t_{i} \\
& +30 \beta \hat{c}_{i} t_{j}+9 \beta c_{j}^{2}+18 \beta c_{j} \hat{c}_{j}+18 \beta c_{j} t_{i}-54 \beta c_{j} t_{j}-7 \beta \hat{c}_{j}^{2}-30 \beta \hat{c}_{j} t_{i}-6 \beta \hat{c}_{j} t_{j} \\
& \left.-63 \beta t_{i}^{2}+18 \beta t_{i} t_{j}+45 \beta t_{j}^{2}\right]
\end{aligned}
$$

where $i, j=1,2$ and $i \neq j$. Having derived the welfare of the $i$ th country as a function of the trade policies set by the two governments, the marginal costs of the two firms, and the two firms' beliefs about their competitor's marginal cost, it is now possible to analyze the first stage of the game where the two governments set their trade policy.

\section{Trade Policy as a Signal of Costs}

With complete information, the trade policy set by a government affects national welfare through its direct strategic effect on the outputs of the two firms, but with incomplete information there is an additional signalling effect. The trade policy set by a government can be used by the foreign firm to infer the marginal cost of the domestic firm, and the foreign firm's beliefs about the marginal cost of the domestic firm will affect its output decision. The two governments will take this signalling effect into account when they set their trade policies. This section derives the separating equilibria of this signalling game when only one country signals the costs of its firm while 
taking the expected trade policy of the other country as given. ${ }^{14}$

To solve for the separating equilibria of this game, assume that trade policy of the $i$ th country in the separating equilibrium is given by $t_{i}=\phi_{i}\left(c_{i} ; \bar{t}_{j}\right)$, where $\phi_{i}$ is a differentiable monotonic function of the domestic firm's marginal cost, $c_{i}$, and $\bar{t}_{j}$ is the expected trade policy of the $j$ th country which is taken as given. In a separating equilibrium, $t_{i}=\phi_{i}\left(c_{i} ; \bar{t}_{j}\right)$ must satisfy the incentive compatibility constraint that the government in the $i$ th country maximizes its welfare given the beliefs of the foreign firm, and that the beliefs of the foreign firm about the domestic firm's marginal cost are consistent with the separating equilibrium strategy. Beliefs are consistent with the separating equilibrium strategy if they are formed by inverting the separating equilibrium trade policy to obtain $\hat{c}_{i}\left(t_{i}\right)=\phi_{i}^{-1}\left(t_{i} ; \bar{t}_{j}\right)$; hence, the foreign firm can correctly infer the domestic firm's marginal cost from the trade policy set by the government of the $i$ th country in the separating equilibrium. Thus, the government of the $i$ th country will choose $t_{i}=\phi_{i}\left(c_{i} ; \bar{t}_{j}\right)$ to maximize $W_{i}\left(t_{i}, c_{i}, \hat{c}_{i}\left(t_{i}\right)\right)$ where $\hat{c}_{i}\left(t_{i}\right)=\phi_{i}^{-1}\left(t_{i} ; \bar{t}_{j}\right)$; which yields the following first-order condition for welfare maximization:

$$
\frac{d W_{i}}{d t_{i}}=\frac{\partial W_{i}}{\partial t_{i}}+\frac{\partial W_{i}}{\partial \hat{c}_{i}} \frac{d \hat{c}_{i}}{d t_{i}}=0 \quad i, j=1,2 \quad i \neq j
$$

In a separating equilibrium, the firms correctly infer the marginal costs of their foreign competitors from the trade policy set by the domestic government, so $\hat{c}_{i}\left(t_{i}\right)=c_{i}$. Using this, and noting that $d \hat{c}_{i} / d t_{i}=\left(d \phi_{i} / d c_{i}\right)^{-1}$, the differential equation (20) can be rewritten as:

$$
\frac{d \phi_{i}}{d c_{i}}=\frac{-\partial W_{i} / \partial \hat{c}_{i}}{\partial W_{i} / \partial t_{i}}=\frac{4 \alpha-14 \beta c_{i}+10 \beta \bar{c}_{j}-3 \beta t_{i}-15 \beta \bar{t}_{j}}{3\left(4 \alpha-2 \beta c_{i}-2 \beta \bar{c}_{j}-21 \beta t_{i}+3 \beta \bar{t}_{j}\right)} \quad i, j=1,2 \quad i \neq j
$$

The separating equilibrium trade policy function is a particular solution of the differential equation (21) that satisfies the relevant initial value condition. In general, finding an analytical solution to the differential equation would be very messy, but is unnecessary since a qualitative analysis of the differential equation will yield sufficient information about the separating

14. This game of incomplete information will also have a number of pooling equilibria and these are discussed in the appendix. 
equilibrium. The first step in the qualitative analysis of the differential equation is to plot in $\left(c_{i}, t_{i}\right)$ space the locus where the numerator is zero $(N=0)$ and the locus where the denominator is zero $(D=0)$ in figure 3 . From equation (11), it can be seen that the $D=0$ locus gives the optimal tariff under complete information as a function of the marginal cost of the domestic firm, $t_{i}^{*}\left(c_{i}\right)$. These loci are both linear, and intersect where the marginal cost of the domestic firm is $c_{i}^{0} \equiv\left(2 \alpha+6 \beta \bar{c}_{j}-9 \beta \bar{t}_{j}\right) / 8 \beta$ and the trade policy of the ith country is $t_{i}^{0} \equiv\left(2 \alpha-2 \beta \bar{c}_{j}+3 \beta \bar{t}_{j}\right) / 12 \beta$. Noting that the numerator is negative (positive) above (below) the $\mathrm{N}=0$ locus and the denominator is negative (positive) above (below) the $D=0$ locus, it is possible to sign the derivative in (21) and hence plot a qualitative solution to the differential equation starting from any point in figure 3 . There are two linear solutions of the differential equation for which explicit solutions can be obtained by positing a solution of the form: $\phi_{i}\left(c_{i}\right)-\phi_{i}\left(c_{i}^{0}\right)=k\left(c_{i}-c_{i}^{0}\right)$. Substituting this solution into the differential equation and noting that $d \phi_{i} / d c_{i}=k$, yields the quadratic $63 k^{2}+3 k-14=0$ which has a negative solution $k=(-1-\sqrt{393}) / 42$ labeled as $A$ in figure 3 and a positive solution $k=(-1+\sqrt{393}) / 42$ labeled as $B$. Also shown is the locus where net imports of the ith country are zero $\left(m_{i}=0\right)$, obtained from equation (18) with $\hat{c}_{i}=c_{i}$, and it is easily shown that the country is a net exporter (importer) in the region above (below) this locus.

The next step in the qualitative analysis of the differential equation is to determine the initial value condition that selects the particular solution. It turns out that there are three distinct cases to be considered depending upon the cost parameters, but two of these cases have already been analyzed by Collie and Hviid [1993, 1999] under segmented markets and will only be considered briefly in this paper.

In the first case, illustrated in figure 3 , the distribution of marginal cost is such that $c_{i}^{H}=c_{i}^{H X}<c_{i}^{0}$ so that the ith country is always a net exporter as in Collie and Hviid [1993]. Below the $N=0$ locus, the numerator in (21) is positive so the $i$ th country's welfare is decreasing in the beliefs of the foreign firm about the domestic firm's marginal cost, $\partial W_{i} / \partial \hat{c}_{i}<0$; hence, the government would like the foreign firm to believe that the domestic firm has low costs and the worst beliefs for the government are when $\hat{c}_{i}=c_{i}^{H X}$. When 


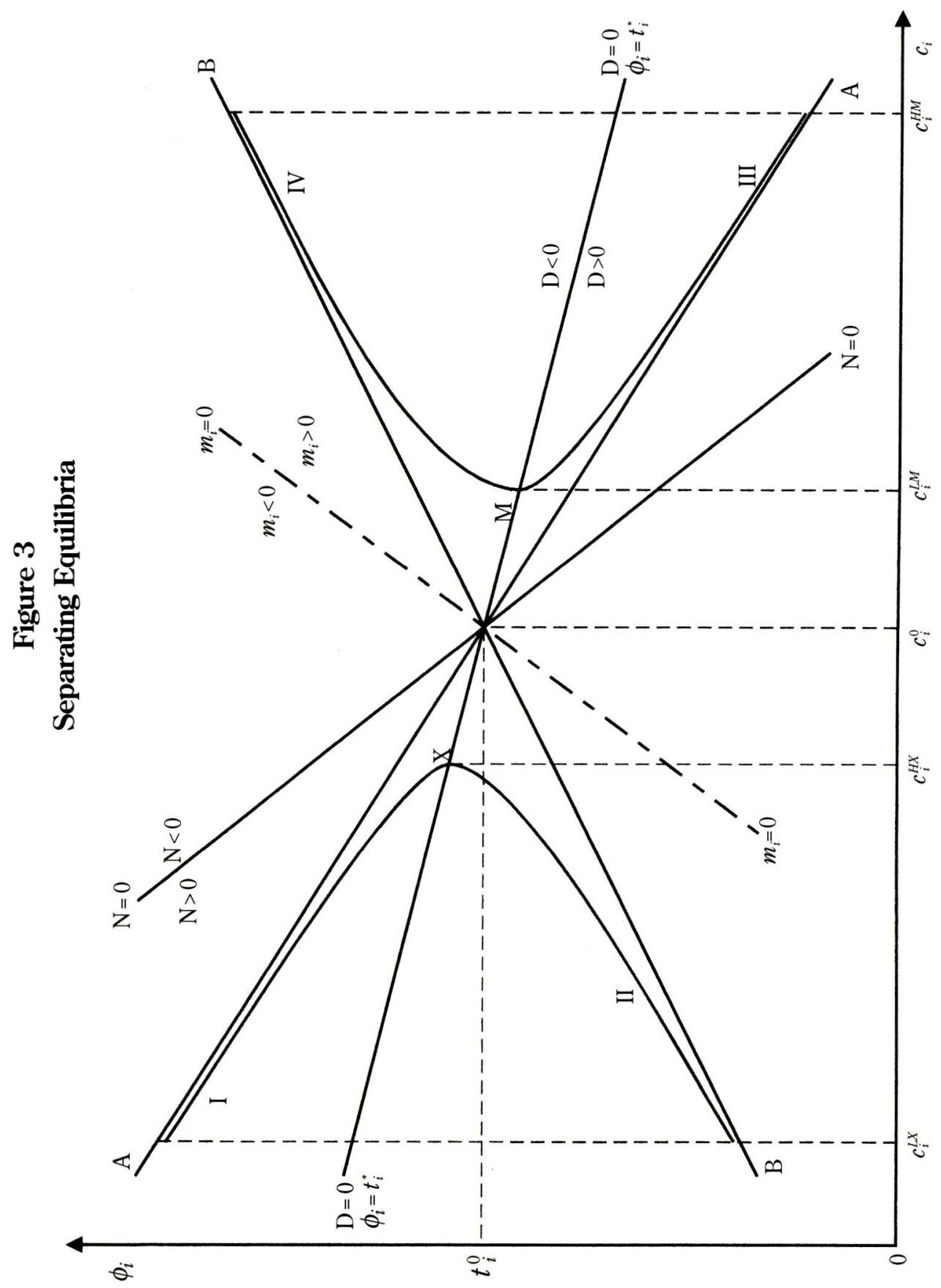


$c_{i}=c_{i}^{H X}$, since the true marginal cost of the domestic firm will be revealed in the separating equilibrium, there is no incentive for the government to set any export subsidy other than the optimal export subsidy under complete information; hence, the initial value condition is that $\phi_{i}\left(c_{i}^{H X}\right)=t_{i}^{*}\left(c_{i}^{H X}\right)$.

Starting from the initial value condition at $X$ there are two possible solutions, I and II, shown in figure 3 , but the second order condition for welfare maximization can be used to eliminate II. ${ }^{15}$ Therefore, the unique separating equilibrium of this game is given by the solution with a negative slope and labeled as I in figure 3 . Inspection of figure 3 shows that the export subsidy in the separating equilibrium is larger than the optimal export subsidy under complete information, represented by the $D=0$ locus. As in Collie and Hviid [1993], the government signals the competitiveness of the domestic firm by using an export subsidy that is larger than the optimum under complete information.

In the second case, illustrated in figure 3 , the distribution of marginal cost is such that $c_{i}^{L}=c_{i}^{L M}>c_{i}^{0}$ so that the country is always a net importer as in Collie and Hviid [1999]. Above the $N=0$ locus, the numerator in (21) is negative so the $i$ th country's welfare is increasing in the beliefs of the foreign firm about the domestic firm's marginal cost $\partial W_{i} / \partial \hat{c}_{i}>0$; hence, the government would like the foreign firm to believe that the domestic firm has high costs and the worst beliefs for the government are when $\hat{c}_{i}=c_{i}^{L M}$. When $c_{i}=c_{i}^{L M}$, since the true marginal cost of the domestic firm will be revealed in the separating equilibrium, there is no incentive for the government to set any tariff other than the optimal tariff under complete information; hence, the initial value condition is that $\phi_{i}\left(c_{i}^{L M}\right)=t_{i}^{*}\left(c_{i}^{L M}\right)$. Starting from the initial value condition at $M$ in figure 3 there are two possible solutions labeled as III and IV but, as above, the second order condition for welfare maximization can be used to eliminate IV. Therefore, the unique separating equilibrium of this game is given by the solution III in figure 3 . Inspection of figure 3 shows that the tariff in the separating equilibrium is smaller than the optimal tariff under complete information, represented by the $D=0$ locus. As in Collie and Hviid [1999], the government signals the

15. The second-order condition for welfare maximization is derived in Collie and Hviid [1993] following Mailath [1987]. 
uncompetitiveness of the domestic firm by using a tariff that is smaller than the optimum under complete information.

In the third case, illustrated in figure 3 , the distribution of marginal cost is such that $c_{i}^{0} \in\left[c_{i}^{L}, c_{i}^{H}\right]$ so the country can be either a net exporter or a net importer depending upon the costs of the domestic firm. The previous two cases both satisfied the conditions required for the existence and uniqueness of a separating equilibrium in Mailath [1987], but belief monotonicity is not satisfied in this case since $\partial W_{i} / \partial \hat{c}_{i}<0$ below the $N=0$ locus and $\partial W_{i} / \partial \hat{c}_{i}>0$ above the $N=0$ locus. ${ }^{16}$ In this case, the worst beliefs for the government are when $\hat{c}_{i}=c_{i}^{0}$ where there is actually no incentive to signal since $\partial W_{i} / \partial \hat{c}_{i}=0$; hence, the domestic government will set the optimal trade policy under complete information and the initial value condition is that $\phi_{i}\left(c_{i}^{0}\right)=t_{i}^{*}\left(c_{i}^{0}\right)=t_{i}^{0}$. The two solutions that satisfy the initial value condition are the linear solutions labeled as $A$ and $B$ in figure 3 . In this case it is not possible to use the second order condition for welfare maximization to eliminate one of the possible solutions as it is satisfied by both solutions. However, it can be shown that $A, \phi_{i}^{A}\left(c_{i}\right)$, Pareto dominates $B, \phi_{i}^{B}\left(c_{i}\right)$, since it yields higher welfare for all values of marginal cost except $c_{i}=c_{i}^{0}$; the difference in welfare between the two solutions can be shown to be:

$$
W_{i}\left(c_{i}, c_{i}, \phi_{i}^{A}\left(c_{i}\right)\right)-W_{i}\left(c_{i}, c_{i}, \phi_{i}^{B}\left(c_{i}\right)\right)=\frac{\sqrt{393}}{168}\left(c_{i}-c_{i}^{0}\right)^{2} \geq 0
$$

Since $B$ can be ruled out by Pareto-dominance, the unique separating equilibrium is given by $A$ in figure 3 . This seems to be intuitively reasonable as the separating equilibria in the other two cases both converge towards $\mathrm{A}$. Inspection of figure 3 shows that the government uses a larger (smaller) export subsidy (import tariff) than the optimum under complete information, represented by the $D=0$ locus. Thus, the results in all three cases can be summarized by the following proposition:

16. In Mailath [1987], the conditions required for the existence and uniqueness of a separating equilibrium in games with a continuum of types are belief monotonicity, type monotonicity, and single-crossing. 
Proposition 3: The export subsidy (import tariff) in the separating equilibrium is larger (smaller) than the optimal export subsidy (import tariff) under complete information.

The intuition for these results requires an understanding of the marginal costs of signalling. In this model, the marginal cost of signalling for the country is the marginal welfare loss from setting a trade policy that deviates from the optimum under complete information, $\left|\partial W_{i} / \partial t_{i}\right|$. Figure 4 shows the marginal welfare effect of trade policy as a function of the domestic firm's cost when trade policy is larger than the optimum, $t_{i}>t_{i}^{*}$ so $\partial W_{i} / \partial t_{i}<0$, and when it is smaller than the optimum, $t_{i}>t_{i}^{*}$ so $\partial W_{i} / \partial t_{i}>0$. As the domestic firm's cost increases, the main effect is to reduce the profit-margin of the domestic firm thus weakening the profit-shifting effect, and thereby reducing the marginal welfare gain from using trade policy, $\partial^{2} W_{i} / \partial c_{i} \partial t_{i}<0$. Thus, the marginal cost of signalling with a trade policy below (above) the optimum is decreasing (increasing) in the domestic firm's cost, and is lowest when the domestic firm has the highest (lowest) possible costs.

When the country is a net exporter, the government would like the foreign firm to believe that the domestic firm has low costs as this will lead the foreign firm to reduce its output. This increases the welfare of the country since profits are shifted to the domestic firm and there is an improvement in the terms of trade. The government signals the competitiveness of the domestic firm by setting an export subsidy larger than the optimum under complete information because, in this case, the marginal cost of signalling is increasing in the domestic firm's cost. When the country is a net importer, the government would like the foreign firm to believe that the domestic firm has high costs as this will lead the foreign firm to increase its output thereby reducing the price of imports. This increases the welfare of the domestic country since the terms of trade and tariff revenue gains exceed the profitshifting loss of the domestic firm. The government signals the uncompetitiveness of the domestic firm by setting a tariff smaller than the optimum under complete information because, in this case, the marginal cost of signalling is decreasing in the domestic firm's cost. 
Figure 4

The Marginal Cost of Signalling

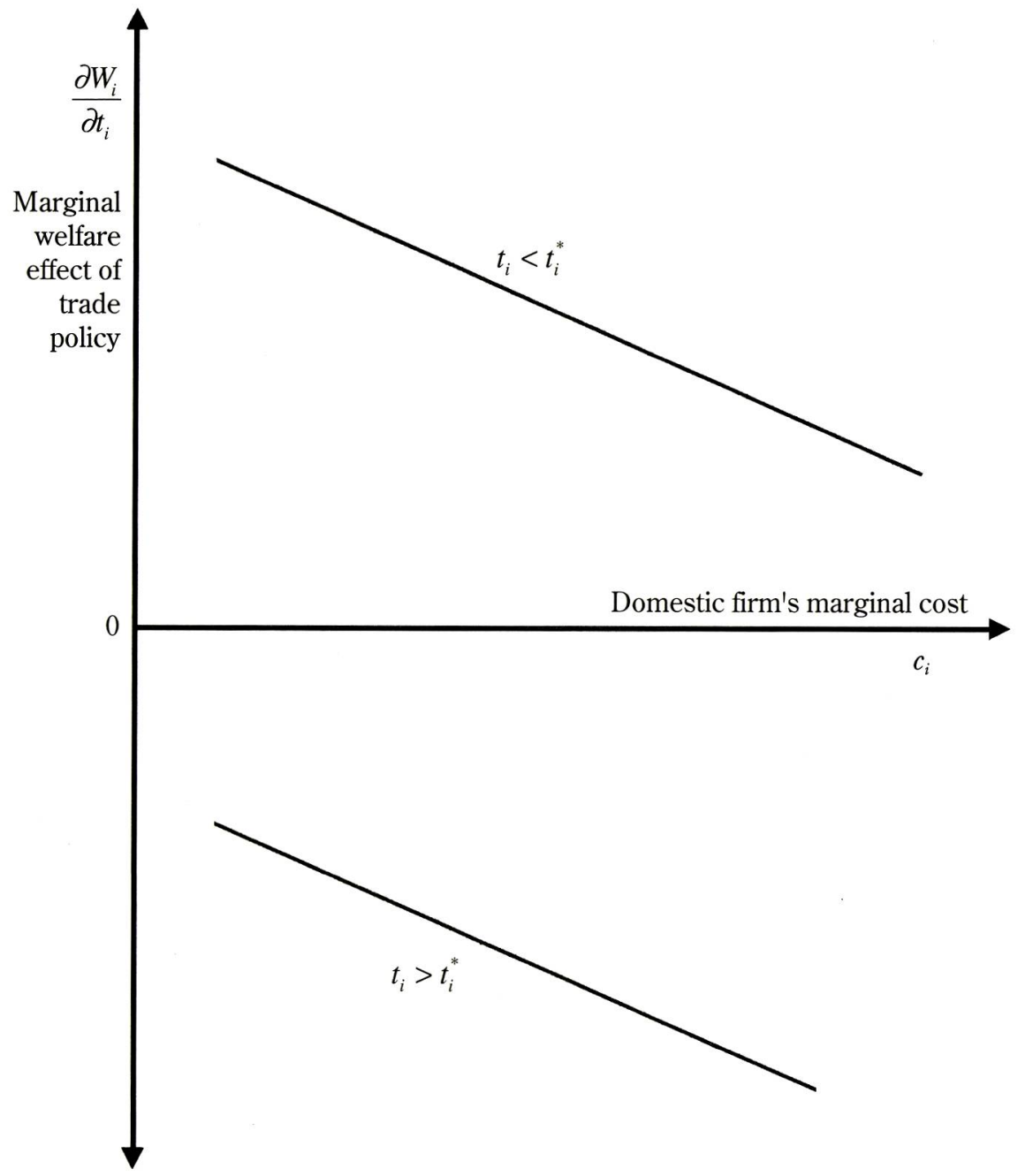

\section{Simultaneous Signalling Game}

Having derived the separating equilibrium of this signalling game with the expected trade policy of the other country taken as given, it is now possible to solve the separating equilibrium of the simultaneous signalling game when both governments use trade policy as a signal of their firms' 
costs. As both countries simultaneously set their trade policy at the first stage of the game, they will only observe the other country's trade policy after they have set their own trade policy. Therefore, the two governments must set their trade policy knowing only the expected costs of the foreign firm and the expected trade policy of the other country. The expected trade policy of the other country is obtained by taking expectations of the separating equilibrium trade policy given the distribution of the foreign firm's marginal costs. In the separating equilibrium of the simultaneous signalling game, each government sets its separating equilibrium trade policy $\phi_{i}\left(c_{i} ; \bar{t}_{j}\right)$ where its expectation of the other country's trade policy is rational; thus, the following conditions must be satisfied:

$$
t_{i}=\phi_{i}\left(c_{i} ; \bar{t}_{j}\right) \text { and } \bar{t}_{j}=E_{i}\left[\phi_{j}\left(c_{j} ; \bar{t}_{i}\right)\right] \quad i, j=1,2 \quad i \neq j
$$

Since the separating equilibrium trade policies may be non-linear, it is generally not possible to solve explicitly for the separating equilibrium of this simultaneous signalling game. However, in the case when the separating equilibrium trade policy is linear, $t_{i}=t_{i}^{0}+k\left(c_{i}-c_{i}^{0}\right)$, where $c_{i}^{0} \equiv\left(2 \alpha+6 \beta \bar{c}_{j}-9 \beta \bar{t}_{j}\right) / 8 \beta$, $t_{i}^{0} \equiv\left(2 \alpha-2 \beta \bar{c}_{j}+3 \beta \bar{t}_{j}\right) / 12 \beta$, and $k=(-1-\sqrt{393}) / 42$, an explicit solution can easily be obtained. Taking expectations of the linear separating equilibrium trade policy yields the best-reply functions of the two countries in terms of their expected trade policies:

$$
\bar{t}_{i}=\frac{1}{6 \beta}\left(\alpha-\beta \bar{c}_{j}\right)-\frac{k}{4 \beta}\left(\alpha-4 \beta \bar{c}_{i}+3 \beta \bar{c}_{j}\right)+\frac{2+9 k}{8} \bar{t}_{j} \quad i, j=1,2 \quad i \neq j
$$

These best-reply functions are shown in figure five. Since the best-reply functions are downward sloping, $d \bar{t}_{i} / d \bar{t}_{j}=(2+9 k) / 8 \approx-0.31$, the expected trade policies of the two countries are strategic substitutes whereas trade policies were strategic complements under complete information. The expected trade policies of the two countries in the separating equilibrium of the simultaneous signalling game are given by the intersection of the two best-reply functions, and can be obtained by solving the simultaneous equations (24): 


\section{Figure 5 \\ Simultaneous Signalling Equilibrium}

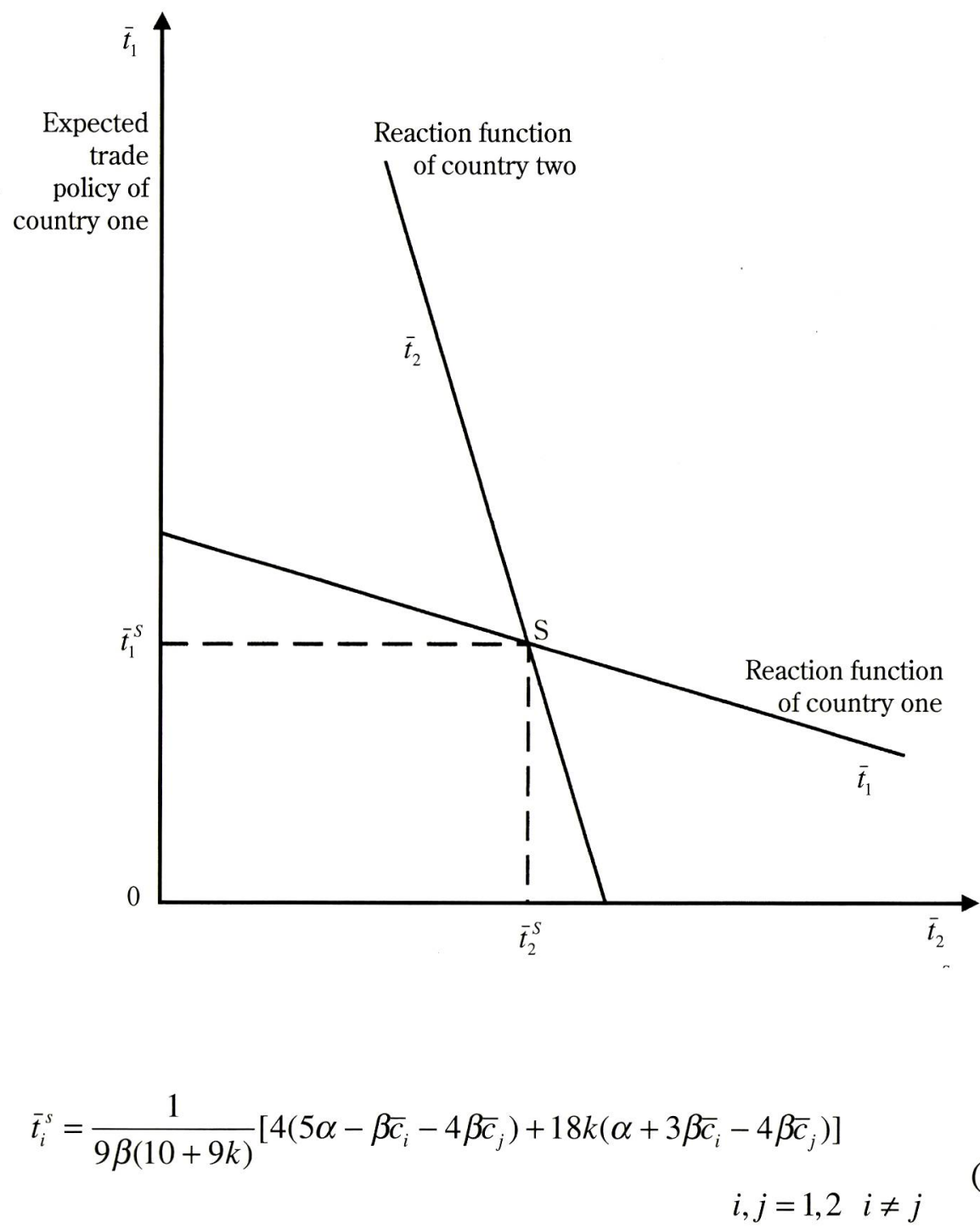

Having obtained the expected trade policies of the two countries these can be substituted back into (23) to obtain a complete description of the separating equilibrium of the simultaneous signalling game. In the symmetric case, where $\bar{c}_{1}=\bar{c}_{2}=\bar{c}$, the expected trade policy of the two countries is $\bar{t}=\bar{t}_{1}^{S}=\bar{t}_{2}^{S}=2(\alpha-\beta \bar{c}) / 9 \beta>0$ which is equal to the Nash equilibrium 
under complete information when $c_{1}=c_{2}=\bar{c}$. To compare expected trade policies in the asymmetric case, subtract the expected trade policy of the $j$ th country from the expected trade policy of the $i$ th country, to obtain:

$$
\bar{t}_{i}^{s}-\bar{t}_{j}^{s}=\frac{2(2+21 k)}{30+27 k}\left(\bar{c}_{i}-\bar{c}_{j}\right)=\frac{14(\sqrt{393}-3)}{3(137-\sqrt{393})}\left(\bar{c}_{j}-\bar{c}_{i}\right)
$$

Observing that the coefficient on the righthand side is positive leads to the following proposition:

Proposition 4: In the linear separating equilibrium of the simultaneous signalling game, the country that has the firm with the lowest (highest) expected cost has the highest (lowest) expected trade policy and will be an expected net exporter (importer).

This contrasts with the result under complete information in proposition two where both countries set their Nash equilibrium trade policies at exactly the same level. ${ }^{17}$ Since the firm with low (high) expected cost is an expected net exporter (importer), the signalling effect will increase (decrease) its expected trade policy compared to that under complete information.

An interesting question about the separating equilibrium of the simultaneous signalling game is whether intervention by both governments makes the world worse off than under free trade. Since the concern is worldwide efficiency, world welfare can be measured by the sum of domestic and foreign welfare: $\Omega\left(t_{1}, t_{2}, c_{1}, c_{2}, \hat{c}_{1}, \hat{c}_{2}\right)=W_{1}+W_{2}$. Assume that the cost distributions are such that the separating equilibrium of the simultaneous signalling game is the linear solution, $t_{i}^{S}=t_{i}^{0}+k\left(c_{i}-c_{i}^{0}\right)$. In the separating equilibrium, each firm's costs can be inferred from its government's trade policy, so the beliefs of the firms are that $\hat{c}_{i}=c_{i}$. Substituting these values into world welfare and taking expectations yields expected welfare in the separating equilibrium, $\Omega^{S}=E \Omega\left(t_{1}^{S}, t_{2}^{S}, c_{1}, c_{2}, \bar{c}_{1}, \bar{c}_{2}\right)$ :

17. This result is similar to that in de Meza [1986] under segmented markets and with complete information. 


$$
\begin{aligned}
\Omega^{S}= & \frac{4}{9 \beta}\left[\left(\alpha-\beta \bar{c}_{1}\right)^{2}+\left(\alpha-\beta \bar{c}_{2}\right)^{2}\right] \\
& +\frac{28-36 k-9 k^{2}}{36} \beta\left(\bar{c}_{1}-\bar{c}_{2}\right)^{2}+\frac{44-36 k-9 k^{2}}{36} \beta\left(\sigma_{1}^{2}+\sigma_{2}^{2}\right)
\end{aligned}
$$

Under free trade, both countries set their trade policy equal to zero, $t_{1}=t_{2}$ $=0$, so obviously neither firm can infer the costs of its foreign competitor and, hence, the beliefs of both firms are that costs are equal to their expected value, $\hat{c}_{1}=\bar{c}_{1}$ and $\hat{c}_{2}=\bar{c}_{2}$. Substituting these values into world welfare and taking expectations, yields the expected value of welfare under free trade $\Omega^{F}=E \Omega\left(0,0, c_{1}, c_{2}, \bar{c}_{1}, \bar{c}_{2}\right)$ :

$$
\Omega^{F}=\frac{4}{9 \beta}\left[\left(\alpha-\beta \bar{c}_{1}\right)^{2}+\left(\alpha-\beta \bar{c}_{2}\right)^{2}\right]+\frac{7}{9} \beta\left(\bar{c}_{1}-\bar{c}_{2}\right)^{2}+\frac{3}{4} \beta\left(\sigma_{1}^{2}+\sigma_{2}^{2}\right)
$$

To compare expected welfare under free trade with expected welfare in the simultaneous separating equilibrium, subtract (28) from (27) and recall that $k=(-1-\sqrt{393}) / 42$ :

$$
\begin{aligned}
\Omega^{S}-\Omega^{F} & =-\frac{k(4+k)}{4} \beta\left(\bar{c}_{1}-\bar{c}_{2}\right)^{2}+\frac{17-36 k-9 k^{2}}{36} \beta\left(\sigma_{1}^{2}+\sigma_{2}^{2}\right) \\
& =\frac{\beta}{3528}\left[(83 \sqrt{393}-113)\left(\bar{c}_{1}-\bar{c}_{2}\right)^{2}+(83 \sqrt{393}+1553)\left(\sigma_{1}^{2}+\sigma_{2}^{2}\right)\right]>0
\end{aligned}
$$

This is unambiguously positive which leads to the following surprising and counterintuitive proposition:

Proposition 5: In the simultaneous signalling game, expected world welfare is higher in the linear separating equilibrium than under free trade.

There are two reasons for this surprising result: Firstly, under free trade neither firm gains any information about the costs of its foreign competitor whereas in the separating equilibrium the true costs of both firms are revealed. In the separating equilibrium, when a firm learns that its competitor has higher (lower) than average costs it will expand (contract) its own output. Secondly, in the separating equilibrium, the firm with the lowest cost will receive a large export subsidy while the firm with the highest cost will be protected by a small tariff. Both of these effects will increase worldwide 
efficiency compared to free trade since they lead the firm with the lowest cost to expand its output and lead the firm with the highest cost to contract its output. Thus, intervention by both governments leads to greater specialization according to comparative advantage and an increase in the expected welfare of the world. That there is an increase in worldwide efficiency is somewhat paradoxical since each government is motivated by the profitshifting and rent-extracting arguments for intervention, both of which are usually beggar-my-neighbour policies.

In the symmetric case, when the two countries have identical cost distributions, the efficiency gains from increased specialization in the separating equilibrium are divided equally between the two countries so both are better off in the separating equilibrium than under free trade. However, with cost asymmetries, the efficiency gains will not be equally divided. In the Nash equilibrium with complete information, the country with the low cost firm was worse off than under free trade while the other country was better off. Similarly, with incomplete information, the country with the low expected cost firm may be worse off in the separating equilibrium than under free trade while the other country will undoubtedly be better off. ${ }^{18}$

\section{Conclusions}

A model of strategic trade policy under integrated markets has been presented and optimal trade policies have been derived under assumptions of both complete and incomplete information. With complete information, it has been shown that the optimal policy is an import tariff (export subsidy) when a country is a net importer (exporter). In the Nash equilibrium in trade policies, the country that has the firm with the lowest cost gives an export subsidy which is fully countervailed by the import tariff of the other country. The introduction of incomplete information about the costs of the two firms adds an incentive for both governments to use their trade policy as a signal of their domestic firm's cost. As a result of this signalling effect, the export subsidy (import tariff) in the separating equilibrium is larger

18. Obviously, the possibility that country with the low expected cost firm will lose is most likely when the variance of costs is small. 
(smaller) than the optimum under complete information. In the simultaneous signalling game, the country that has the firm with the lowest (highest) expected cost will have the highest (lowest) expected trade policy in the separating equilibrium. Expected world welfare in the separating equilibrium is higher than under free trade and, in the symmetric case, both governments gain from intervention in the simultaneous signalling game.

This last result is the most significant result in this paper since it provides a rare example where non-cooperative trade policy setting leads to higher welfare for both countries than under free trade. Intervention by both governments results in the true costs of the two firms being truthfully revealed with the most efficient firm receiving a large export subsidy and the least efficient being protected by a small tariff. Compared to free trade, this leads to an expansion (contraction) of the most (least) efficient firm and a welfare gain from increased specialization according to comparative advantage. Intervention can increase welfare because imperfect competition and incomplete information do not allow the full gains from comparative advantage to be exploited.

\section{References}

Anis, A.H. and T.W. Ross [1992], "Imperfect Competition and ParetoImproving Strategic Trade Policy," Journal of International Economics $33 ; 363-371$.

Bagwell, K. and R.W. Staiger [1989], "The Role of Export Subsidies when Product Quality is Unknown,” Journal of International Economics 27; 69-89.

Brainard, S.L. and Martimort, D. [1996], "Strategic Trade Policy Design with Asymmetric Information and Public Contracts," Review of Economic Studies 63; 81-105.

Brander, J.A. [1995], "Strategic Trade Policy," in G.M. Grossman and K. Rogoff (Eds.), Handbook of International Economics III, North Holland, Amsterdam.

Brander, J.A. and Spencer, B.J. [1984], "Trade Warfare: Tariffs and Cartels," Journal of International Economics 16; 227-242.

Brander, J.A. and Spencer, B.J. [1985], "Export Subsidies and International 
Market Share Rivalry,” Journal of International Economics 18; 83-100. Bulow, J., J. Geanakoplos and P. Klemperer [1985], "Multimarket Oligopoly: Strategic Substitutes and Complements," Journal of Political Economy 93; 488-511.

Collie, D.R. [1994], "Endogenous Timing in Trade Policy Games: Should Governments Use Countervailing Duties?," Weltwirtchaftiches Archiv 130; 191-209.

Collie, D.R. [1998], "Trade Policy under Bertrand Duopoly with Integrated Markets: the Pure Strategy Equilibrium," Economics Letters 60; 179183.

Collie, D.R. and Hviid, M. [1993], "Export Subsidies as Signals of Competitiveness," Scandinavian Journal of Economics 95; 327-339.

Collie, D.R. and Hviid, M. [1999], "Tariffs as Signals of Uncompetitiveness," Review of International Economics 7; 571-579.

Dixit, A.K. [1984], "International Trade Policy for Oligopolistic Industries," Economic Journal 94, Supplement; 1-16.

Dixit, A.K. [1988], "Anti-dumping and Countervailing Duties under Oligopoly," European Economic Review 32; 55-68.

Fisher, E. O'N [1985], Three Essays in International Trade Theory, PhD Thesis, University of California, Berkeley.

Fisher, E. O’N and C.A. Wilson [1995], "Price Competition between Two International Firms Facing Tariffs," International Journal of Industrial Organization 13; 67-87.

Johnson, H.G. [1953-54], "Optimum Tariffs and Retaliation,” Review of Economic Studies 21; 142-153.

Mailath, G.J. [1987], "Incentive Compatibility in Signalling Games with a Continuum of Types,” Econometrica 55; 1349-1365.

Markusen, J.R. [1981], "Trade and Gains from Trade with Imperfect Competition," Journal of International Economics 11; 531-551.

Markusen, J.R. and Venables, A.J. [1988], "Trade Policy with Increasing Returns and Imperfect Competition: Contradictory Results from Competing Assumptions," Journal of International Economics 24; 299-316.

de Meza, D. [1986], "Export Subsidies and High Productivity: Cause or Effect," Canadian Journal of Economics 19; 347-350.

Qiu, L.D. [1994], “Optimal Strategic Trade Policy under Asymmetric Infor- 
mation," Journal of International Economics 36; 333-354.

Venables, A.J. [1994], "Tariffs and Subsidies with Price Competition and Integrated Markets; The Mixed Strategy Equilibria," Oxford Economic Papers 46; 30-44.

\section{Appendix: Pooling Versus Separating Strategies}

Obviously, the simultaneous signalling game analyzed in this paper has a number of pooling equilibrium in addition to the unique separating equilibrium. The obvious candidate for a pooling equilibrium is for each country to set its trade policy equal to the Nash equilibrium trade policy under complete information (12) with $c_{i}=\bar{c}$ so that $t_{i}=\bar{t}=2(\alpha-\beta \bar{c}) 9 \beta$, which is the same as the expected trade policy in the separating equilibrium, where the equilibrium beliefs are that $\hat{c}_{i}=\bar{c}$. This pooling equilibrium can be sustained by the out of equilibrium beliefs that $\hat{c}_{i}=c_{i}^{L}$ if $t_{i}<\bar{t}$ and $\hat{c}_{i}=c_{i}^{H}$ if $t_{i}>\bar{t}$.

To compare pooling and separating strategies, suppose the two countries can each choose between these two strategies at the start of the game. Then, the expected welfare of the countries in the four possible outcomes can be shown to be:

$$
\begin{aligned}
W^{S S} & =E W_{i}\left(t_{i}^{S}, c_{i}, c_{i} ; t_{j}^{S}, c_{j}, c_{j}\right)=\frac{4}{9 \beta}(\alpha-\beta \bar{c})^{2}+\frac{44-36 k-9 k^{2}}{36} \beta \sigma^{2} \\
W^{P P} & =E W_{i}\left(\bar{t}, c_{i}, \bar{c} ; \bar{t}, c_{j}, \bar{c}\right)=\frac{4}{9 \beta}(\alpha-\beta \bar{c})^{2}+\frac{3}{4} \beta \sigma^{2} \\
W^{S P} & =E W_{i}\left(t_{i}^{S}, c_{i}, c_{i} ; \bar{t}, c_{j}, \bar{c}\right)=\frac{4}{9 \beta}(\alpha-\beta \bar{c})^{2}+\frac{77-12 k-63 k^{2}}{72} \beta \sigma^{2} \\
W^{P S} & =E W_{i}\left(\bar{t}, c_{i}, \bar{c} ; t_{j}^{S}, c_{j}, c_{j}\right)=\frac{4}{9 \beta}(\alpha-\beta \bar{c})^{2}+\frac{65-60 k+45 k^{2}}{72} \beta \sigma^{2}
\end{aligned}
$$

where the first superscript indicates the strategy of the country under consideration; the second superscript indicates the strategy of the other country; $P$ denotes pooling; and $S$ denotes separating. Note that welfare in the pooling equilibrium is the same as welfare under free trade (28). Comparing the expected welfare of a country when it separates with that when it pools given the strategy of the other country yields: 


$$
\begin{aligned}
& W^{S S}-W^{P S}=\frac{23-12 k-63 k^{2}}{72} \beta \sigma^{2}=\frac{43+\sqrt{393}}{336} \beta \sigma^{2}>0 \\
& W^{S P}-W^{P P}=\frac{23-12 k-63 k^{2}}{72} \beta \sigma^{2}=\frac{43+\sqrt{393}}{336} \beta \sigma^{2}>0
\end{aligned}
$$

Since these are both positive, separating dominates pooling whatever the strategy of the other country therefore both countries will choose the separating strategy and the outcome will be the separating equilibrium; this leads to the following proposition:

Proposition A1. In the symmetric case, for both governments, the separating strategy dominates the pooling strategy and the outcome will be the separating equilibrium.

The pooling equilibrium can be ruled out as a reasonable outcome of this game for at least two reasons. Firstly, as proposition A1 makes clear, for each country the pooling strategy is Pareto-dominated by the separating strategy. Secondly, the out of equilibrium beliefs supporting the pooling equilibrium are unreasonable since a country that sets a trade policy larger (smaller) than the pooling equilibrium tariff is assumed to have high (low) costs even though such a country would have the least incentive to set this trade policy. 